\title{
Health benefits of soy beans and soy products: a review
}

\author{
Christina S Venter
}

\section{OPSOMMING}

Sojabone is volop, ekonomiese dieetbronne van proteïen. Tans word gefokus op die moontlike rol van sojabone in die voorkoming en behandeling van sekere degeneratiewe Westerse siektes soos hart- en bloedvatsiektes, osteoporose en sekere tipes kanker. Heel sojabone bevat $40 \%$ proteïene, terwyl sojameel, sojaproteïenkonsentraat en geïsoleerde sojaproteïen respektiewelik $50 \%, 70 \%$ en $90 \%$ proteïen bevat. Verskeie nie-nutriëntbestanddele soos isoflavone, protease-inhibeerders, fitiensuur, saponiene en fitosterole kom in sojabone voor en is moontlik vir sekere van die voordelige gesondheidseienskappe van sojabone verantwoordelik. Die cholesterolverlagende effek van sojabone mag te danke wees aan die aminosuursamestelling daarvan, en/of verlaagde cholesterolabsorpsie of galsoutherabsorpsie, verhoogde laedigtheidlipoproteïen(LDL-) reseptoraktiwiteite, verlaagde lewercholesterolsintese, anti-oksidantaktiwiteit of verhoogde plasmatiroksienvlakke. Die nienutriëntbestanddele van sojabone mag vir die cholesterolverlagende, antikarsinogeniese en beenversterkende effek verantwoordelik wees. Meer navorsing is nodig om die meganismes op te klaar waardeur sojabone en sojaprodukte die gesondheid van die mens beïnvloed.

\section{- Prof CS Venter}

Department of Nutrition and Family Ecology, PU for CHE, Potchefstroom

\section{INTRODUCTION}

Soy beans has been a food in China for thousands of years. It is an abundant, economic source of protein. No other nation has acquired the same taste for soy beans as the Chinese and Japanese, but the bean has become an important raw material for the international food industry. Attention has recently focused on the possible role of soy beans in the diet for the prevention and treatment of degenerative Western diseases (Anderson et al, 1995a; Knight \& Eden, 1996; Kurzer \& Xu, 1997; Potter, 1998). Several studies documented the hypocholesterolaemic effects of soy beans (Anderson et al, 1995b, Potter, 1998), the anticarcinogenic effects of soy beans (Barnes et al, 1996), and the ability of soy beans to lower the risk of osteoporosis (Adlercreutz \& Mazur, 1997).

The purpose of this review is to describe the physiological and biochemical effects of soy bean components in the body, and their possible prevention of the above diseases. Recommendations are submitted for further research in this regard and on the amounts that may safely be included in the human diet.

\section{COMPOSITION OF SOY BEANS}

Soy beans are classified as oil seeds, not as dry beans. Table 1 contains the nutrient composition of $100 \mathrm{~g}$ of cooked dried haricot, kidney and soy beans (Langenhoven et al, 1991), and Table 2 presents the percentage contribution of the macronutrients in soy and dry beans to the total energy content. Whole dry soy beans contain about $40 \%$ protein (twice as much as most other pulses) and up to $20 \%$ fat. Whole soy beans are a good source of calcium, iron, zinc, phosphorus, magnesium, thiamin, riboflavin, niacin and folacin.

It was recently recognised that the human diet contains, in addition to essential macro and micronutrients, a complex array of naturally occurring bioactive nonnutrients called phytochemicals (plant-derived compounds) that confer significant long-term health benefits (Setchell, 1998). Among these phytochemicals is the broad class of nonsteroidal oestrogens called phytoestrogens that also behave as oestrogen mimics. The major classes of phytoestrogens that are of interest from a nutritional and health perspective, are the lignans and the isoflavones. Soy beans contain large amounts of the isoflavones diadzein, genistein an glycitein (1-3 mg/g) and their acetyl and malonyl conjugates (Song et al, 1998). Studies have shown that concentration and composition vary in different soy beans or soy protein products (Murphy, 
TABLE 1: $\quad$ THE NUTRIENT COMPOSITION OF DRY AND SOY BEANS* COMPARED TO RECOMMENDED DIETARY ALLOWANCES**

\begin{tabular}{|c|c|c|c|c|}
\hline \multirow[t]{2}{*}{ Nutrient } & \multicolumn{3}{|c|}{$100 \mathrm{~g}$ cooked beans } & \multirow[t]{2}{*}{ RDA ** } \\
\hline & Haricot & Kidney & Soy & \\
\hline Moisture (\%) & 69,6 & 70,5 & 62,6 & \\
\hline Energy (kJ) & 413 & 423 & 706 & \\
\hline Protein $(\mathrm{g})$ & 6,6 & 7,1 & 16,6 & 63,0 \\
\hline Fat $(g)$ & 0,5 & 0,3 & 9,0 & \\
\hline Saturated fatty acids (g) & - & - & 1,3 & \\
\hline Monounsaturated fatty acids (g) & - & - & 2,0 & \\
\hline Polyunsaturated fatty acids (g) & - & - & 5,1 & \\
\hline Carbohydrate (g) & 16,6 & 17,1 & 4,8 & \\
\hline Dietary fibre $(\mathrm{g})$ & 7,4 & 5,1 & 1,6 & \\
\hline $\mathrm{NSP}^{\star * *}$ total $(\mathrm{g})$ & 8,3 & 6,7 & 2,9 & \\
\hline Soluble NSP (g) & 3,7 & 3,2 & $0,1^{\star \star \star \star}$ & \\
\hline Insoluble NSP (g) & 4,6 & 3,5 & $2,0^{\star \star \star \star}$ & \\
\hline Calcium (mg) & 65 & 19 & 102 & 800 \\
\hline Iron (mg) & 2,5 & 1,7 & 5,1 & 10 \\
\hline Magnesium (mg) & 45 & 33 & 86 & 350 \\
\hline Phosphorous (mg) & 120 & 87 & 247 & 800 \\
\hline Potassium (mg) & 320 & 400 & 515 & \\
\hline Sodium (mg) & 15 & 16 & 1 & \\
\hline Zinc (mg) & 1,0 & 1,0 & 1,2 & 15,0 \\
\hline Copper (mg) & 0,14 & 0,16 & 0,41 & \\
\hline Thiamin (mg) & 0,11 & 0,14 & 0,16 & 1,5 \\
\hline Ribloflavin (mg) & 0,06 & 0,07 & 0,29 & 1,7 \\
\hline Niacin (mg) & 0,7 & 0,7 & 0,4 & 19,0 \\
\hline $\mathrm{A}(\mathrm{RE})$ & - & - & 1 & 1000,0 \\
\hline $\mathrm{E}(\mathrm{mg} \alpha-\mathrm{TE})$ & - & - & 0,35 & 10,0 \\
\hline Folic acid $(\mu \mathrm{g})$ & - & - & 54 & 200,0 \\
\hline
\end{tabular}

*** RDA: Recommended dietary allowances (Food and Nutrition Board, 1989)

*** NSP: Nonstarch polysaccharides (Englyst et al, 1988)

**** $\quad$ AOAC: Association of Analytical Chemists, In Slavin, 1991

1982) and that this variation is due to species differences (Franke et al, 1995), geographic and environmental conditions (Eldridge \& Kwolek, 1983), and the extent of the industrial processing of soy beans (Murphy, 1982; Coward et al, 1998). Table 3 illustrates the varied isoflavone concentration in a range of soy products.

\section{PROCESSING OF SOY BEANS}

The processing of soy beans as described by Snyder and Kwon (1987:74-78) may be summarised as follows:

Soy beans selected for processing are graded, cleaned, dried to about $10 \%$ moisture content, and 
TABLE 2: CONTRIBUTION OF MACRONUTRIENTS TO TOTAL ENERGY CONTENT OF DRY AND
SOY BEANS *

\begin{tabular}{|c|c|c|c|c|}
\hline & \multicolumn{2}{|c|}{ Percentage contribution of total energy } & Deans & Dietary goals \\
\hline Nutrient & \multicolumn{2}{|c|}{ Kidney } & Soy & $<30$ \\
\hline Total fat & Haricot & 2,7 & 48,4 & $<10$ \\
\hline Saturated & 4,6 & - & 7,0 & 10 \\
\hline Monounsaturated & - & - & 10,7 & 10 \\
\hline Polyunsaturated & - & - & 27,5 & $\geq 60$ \\
\hline Carbohydrate & - & 68,7 & 11,6 & $10-15$ \\
\hline
\end{tabular}

* $\quad$ Based on nutrient composition in Table 1

cracked to remove the hull. Soy bean hulls are processed to create fibre additives for breads, cereals, snacks and livestock feed. After dehulling, the beans are rolled into full-fat flakes that may be used in animal feed or processed into full-fat flour for various commercial food uses. Flaking ruptures the oil cells in the bean, improving the oil extraction process. The next step is to extract the crude oil which is later refined to produce cooking oil, margarine and shortening. Defatted soy flakes are used to produce animal feed and form the basis of a variety of products for human consumption, including soy flour, soy concentrates and soy isolates. These products are used extensively in manufactured foods to help retain moisture and to improve their shelf life, and they act as emulsifiers and as substitutes for meat in food products. Soy flour is produced by grinding the defatted flakes. The protein content of the flour is approximately $50 \%$. Soy flour adds protein and improves the crust colour and shelf life of baked goods. Soy isolates are produced by a chemical process that withdraws most of the protein from the defatted flake, resulting in a product with about $90 \%$ protein content.
Soy isolates contain no fibre or carbohydrates. Isolates are used in many dairy-like products, including cheese, milk, nondairy frozen desserts, coffee whiteners and meat products. Soy concentrates are prepared by removing the soluble sugars from defatted flakes. Soy concentrates contain about $70 \%$ protein and retain most of the bean's dietary fibre. The concentrates are used in protein drinks, as soup bases and in gravies. Soy flour and soy protein concentrates are used in meat products, primarily because of their fat and water absorption properties. These products are used in a texturised form as extenders in ground meat products, in convenience foods, in pizza toppings, meat and fish spreads, and in poultry products (Snyder \& Kwon, 1987:74).

Texturised protein (textured vegetable protein (TVP)) is produced by the thermoplastic extrusion of defatted soy flour, soy concentrates or soy isolates, moistened and mixed with a variety of additives (Wolf et al, 1981). During the extrusion process, small chunks are produced which, when hydrated, have a chewy texture and a meaty taste (Wolf et al, 1981).

TABLE 3: $\quad$ ISOFLAVONE CONCENTRATION IN SOY PRODUCTS

\begin{tabular}{|l|c|c|c|}
\hline Food & $\begin{array}{c}\text { Daidzein } \\
(\boldsymbol{\mu} \mathbf{g} / \mathbf{g})\end{array}$ & $\begin{array}{c}\text { Genistein } \\
(\boldsymbol{\mu} \mathbf{g} / \mathbf{g})\end{array}$ & $\begin{array}{c}\text { Glycitein } \\
(\boldsymbol{\mu} \mathbf{g} / \mathbf{g})\end{array}$ \\
\hline Toasted soy flour* & 1343,4 & 1509,5 & 242,5 \\
Soy flour* & 829,7 & 834,4 & 142,9 \\
Isolated soy protein* & 789,3 & 1258,0 & 114,2 \\
Textured vegetable protein* & 919,7 & 1092,1 & 98,4 \\
Tofu** & 133,1 & 169,0 & 20,9 \\
Soy milk & 1772,0 & 3804,0 & 327,0 \\
& & & \\
${ }^{*}$ Coward et al, 1998s & & & \\
\hline${ }^{* *}$ Song et al, 1998 & & & \\
\hline
\end{tabular}




\section{CHOLESTEROL-LOWERING PROPERTIES OF SOY}

\section{Potential cholesterol-lowering effects}

The judicious substitution of soy for animal protein reduces saturated fat and cholesterol intakes, indirectly resulting in a more favourable blood cholesterol level and potentially reducing the risk of coronary heart disease.

The cholesterol-lowering effects of soy protein, compared to animal protein, have been recognised in animals for more than 90 years (Ignatowsky, 1908 in Anderson et al, 1995). A number of human studies over the past 20 years have shown that the daily consumption of $30 \mathrm{~g}$ to $60 \mathrm{~g}$ of soy protein contributes to a decrease in total and LDL cholesterol of between $10 \%$ and $20 \%$ in individuals with elevated serum cholesterol (Carroll, 1991). High-density lipoprotein (HDL) cholesterol either remains unchanged or is in creased under these circumstances (Anderson et al, 1995b; Baum et al, 1998). In addition, a significant $10 \%$ reduction in triglycerides has been reported in several studies, as noted in a meta-analysis by Anderson et al (1995b). According to these studies changes in lipid concentrations were independent of changes in body weight and the dietary intake of total fat, saturated fat and cholesterol.

As little as $30 \mathrm{~g}$ to $60 \mathrm{~g}$ of isolated soy protein in muffins, breads, cookies and other commonly eaten bakery items effectively lower raised cholesterol (Potter et al, 1993). Replacing milk with a soy beverage has been shown to decrease total serum cholesterol by $5 \%$ to $10 \%$ and low-density lipoprotein (LDL) cholesterol by $10 \%$ to $20 \%$ within four weeks (Steele, 1992). It is therefore suggested that very modest changes in the diet to include soy products have a measurable effect on the blood lipid levels.

Potential mechanism(s) of soy in lowering serum cholesterol concentrations or the risk of coronary heart disease

The mechanisms responsible for the effects of soy on serum lipoproteins are not well known. Carroll (1991) and Potter (1995) reviewed various hypotheses that are presented in this section. These include the amino acid composition of soy protein, an interruption of the intestinal absorption of bile acids and dietary cholesterol, direct effects on the hepatic metabolism of cholesterol, alteration of the hormone concentration involved in cholesterol metabolism, and the effects of components such as isoflavones, fibre and saponins in soy beans.

Studies on experimental animals have shown that the dietary substitution of amino acids patterned after soy protein produces significantly lower serum cholesterol concentrations than amino acids patterned after casein. The extent of cholesterol lowering, however, is not as great compared to the values in animals that were fed intact soy protein (Huff et al 1977; Tasker \&
Potter, 1993). According to Potter (1995), this indicates that there may be another constituent associated with soy protein that is either lost or liberated during hydrolysis of the protein, to be partly responsible for the cholesterol-lowering effect.

Sugano and Koba (1993) also reported that an indigestible fraction of soy protein lowers the serum and liver cholesterol concentrations. In this study soy protein was digested with microbial proteases, and the digestible and indigestible fractions were fed to rats. The results indicated that progressive replacement of casein with the indigestible fraction progressively lowered the serum and liver cholesterol. Faecal excretion of both neutral and acidic sterols increased in animals that were fed the indigestible fraction. However, when the undigested fraction was treated with a methanol extraction or was digested further, the cholesterollowering effect diminished. There appears to be some component in the indigestible fraction that is either lost or altered upon methanol extraction or further digestion.

Potter (1995) suggests that a component such as a saponin or isoflavone or a peptide-peptide sequence that alters the intestinal absorption of cholesterol and bile acids may be a candidate. According to Oakenfull (1981), only those plant fibres that contain saponins bind bile acids in vitro. Potter et al (1979) suggest that the hypocholesterolaemic action of whole soy protein or protein hydrolysates is attributable to the presence of saponins. In the studies with amino acids patterned after the intact proteins (Nagata et al, 1982; Tanaka et al, 1984), general decreases in serum cholesterol concentrations were noted - albeit less pronounced than when intact soy protein was fed - without influencing faecal bile excretion. Increased bile acid excretion on soy diets was observed primarily in rabbits and rats (Huff \& Carroll, 1980; Nagata et al, 1982; Nagoaka et al, 1997). Reports on other species, including humans, are less consistent (Fumagalli et al, 1982; Grundy \& Abrams, 1983). More recently, however, Wong et al (1996) as quoted by Potter (1998), found increases in the pool size of chenodeoxycholic acid in humans who were given soy protein to eat, but neither the cholesterol absorption nor the cholic acid pool size was affected.

In summary, it appears that when intact proteins are fed, cholesterol-lowering on feeding soy protein may be mediated by enhanced bile acid excretion in certain species. However, when amino acids are fed, cholesterol-lowering may be mediated by another mechanism(s).

Studies in animal models (Huff \& Carroll, 1980; Nagata et al, 1982) have shown that soy protein consumption may directly influence the hepatic metabolism of cholesterol by increasing the activity of 3hydroxy-3-methylglutaryl coenzyme A (HMG CoA) reductase, thereby inhibiting hepatic cholesterol synthesis. Lovati et al (1987) reported a sevenfold increase in LDL receptor activity in humans, resulting in increased clearance of cholesterol from the blood in pa- 
tients with raised serum cholesterol concentrations who consumed a soy protein (Cholsoy) diet compared to a standard low-lipid diet with animal protein.

These results were confirmed by other researchers, as reported by Potter (1998). However, the hypothesis of an activation of LDL receptors in liver cells is still controversial and more extensive studies are needed to ascertain the cholesterol-lowering mechanism of soy beans.

It has been postulated that the consumption of soy protein alters many hormones involved in lipid metabolism (Forsythe, 1986; Scholz-Ahrens et al, 1990). Scholz-Ahrens et al (1990) reported increases in plasma total thyroxine, free thyroxine, and triiodothyronine in minipigs fed soy protein compared to those that were fed casein. Forsythe (1986) and Ham et al (1993) reported decreased cholesterol concentrations and increased plasma thyroxine in gerbils and humans respectively when soy protein was included in the diet. However, Potter (1998) investigated this phenomenon in several studies on animals and humans and did not find consistent results. In one study involving gerbils, soy protein concentrate and soy protein isolate significantly reduced the total and LDL cholesterol concentrations, but only soy protein isolate increased the thyroid hormone concentrations (Potter et al, 1996).

As all these hormones are known to be involved in cholesterol metabolism, it has been proposed that variation in hormone secretion is responsible for the cholesterol-lowering effect of soy protein. Especially with regard to the thyroid hormones, the metabolic effects of hyperthyroidism are very similar to those observed with soy protein feeding. That is, LDL receptor activity increases, HMG CoA reductase activity increases, bile acid excretion increases, and total and LDL cholesterol decrease (Potter, 1995). Some observers, as discussed by Carroll (1991), suggest that changes in the ratio of serum glucagon to insulin in patients on a soy protein diet may be important. High insulin:glukagon ratios are thought to be associated with increased risk of cardiovascular disease because of the stimulation of lipogenesis.

Isoflavones are known to have weak oestrogenic activity in biologic systems. Therefore it is increasingly popular to speculate that the mechanism by which soy beans decrease serum cholesterol is via "estrogenic" effects stimulated by the ingestion of isoflavones (Potter, 1995; Anthony et al, 1996). It is well known that mammalian oestrogens have a significant impact on serum lipids, promoting decreases in LDL and increases in HDL cholesterol. Evidence for an effect of isoflavones on serum cholesterol concentrations has been demonstrated in rats, hamsters, nonhuman primates and humans (Cassidy et al, 1995; Pelletier et al, 1995; Anthony et al, 1996; Balmir et al, 1996; Clarkson et al, 1998). The three primate studies reported by Anthony et al (1994, 1995a, $1995 \mathrm{~b})$ demonstrated that soy protein rich in isoflavones favourably affected serum lipids, and that soy protein from which the oestrogens had been extracted had a minimal effect. The authors concluded that soy isoflavones may account for $60 \%$ to $70 \%$ of the hypocholesterolemic effects of soy beans.

Cassidy et al (1995) reported that human consumption of $45 \mathrm{mg}$ of isoflavonoids per day significantly reduced the total and LDL cholesterol concentrations in young females. Similar findings were reported by Potter et al (1993) and Bakhit et al (1994). In contrast, Nestel et al (1997) reported no significant effect on blood lipid concentrations of $45 \mathrm{mg}$ of the isoflavone genistein, administered over a 5 to 10 -week period. However, a significant improvement in systemic arterial elasticity was found in these women.

The effect of isoflavones on coronary vascular reactivity in an atherosclerotic primate model was studied by Honore et al (1997). They reported that the arteries of females fed a low-isoflavone diet constricted in response to acetylcholine, whereas the arteries of females who were fed a high-isoflavone diet dilated. In a study involving male primates (Anthony et al, 1997), the prevalence of atherosclerotic lesions was the lowest in monkeys fed soy protein plus isoflavones, intermediate in monkeys fed an alcohol-extracted soy protein low in isoflavones, and highest in monkeys fed a mixture of casein and lactalbumin. Another mechanism whereby soy beans may decrease the risk of cardiovascular disease is to lower the susceptibility of LDL cholesterol to oxidation (Lichtenstein, 1998). Isoflavonoids have been reported to inhibit the oxidative modification of LDL by macrophages (Kapiotis et al, 1997), enhance the resistance of LDL to oxidation (De Whalley et al, 1990; Kanazawa et al, 1995), and exhibit antioxidant activities in an aqueous phase (Ruiz-Larrea et al, 1997). Genistein inhibits bovine aortic endothelial cell-mediated and human endothelial cell-mediated LDL oxidation, and protects vascular cells from damage by oxidised LDL (Kapiotis et al, 1997). Nestel et al (1997) did not observe the antioxidative effect of genistein.

The soluble fibre content of soy beans is relatively low (see Table 1). Yet some data demonstrate that soy fibre is effective in lowering serum cholesterol in patients with raised cholesterol levels (Tsai et al, 1983; Shorey et al, 1985; Lo et al, 1986). However, in two studies that investigated whether different amounts of soy protein with and without soy fibre were effective in lowering serum lipids (Potter et al, 1993; Bakhit et al, 1994), no additive cholesterol-lowering effect of soy cotyledon fibre could be demonstrated. According to Potter et al (1993), this may indicate that the cholesterol-lowering effect of soy protein consumption may override the effects others observed with soy cotyledon fibre (Shorey et al, 1985; Lo et al, 1986). The beneficial effects of the insoluble fibre components of soy beans on bowel function (increased stool weight and decreased gastrointestinal transit time) have been demonstrated repeatedly, as discussed by Slavin (1991) in a review article. The fibre component of soy beans is therefore probably not responsible for the cholesterol-lowering effect of soy beans. It is also 
likely that the cholesterol-lowering effect of soy is due to a combination of components acting together, and that the mechanism varies in different species. More work is required to determine the mechanisms of intact soy beans as well as its components in animals and humans. A better understanding of the mechanisms involved would help to optimise the use of dietary soy protein for the treatment of raised cholesterol concentrations.

\section{ANTICARCINOGENIC EFFECTS OF SOY BEANS}

\section{Potential anticarcinogenic effects}

Evidence from epidemiological studies suggests, although not entirely consistently, that soy bean-based diets protect against cancer of the breast (Nagasawa, 1980; Wu et al, 1998), prostate (Severson, 1989; Shimizu et al, 1991) and colon (Watanabe \& Koessel, 1993). An epidemiological study carried out in Singapore found an inverse relation between the consumption of soy bean products and the risk of breast cancer in premenopausal women (Lee et al, 1991), but a subsequent study of Chinese women failed to find a similar association (Yuan et al, 1995). Further evidence that soy may protect against breast cancer development was provided by studies of rodent cancer models in which dietary soy supplements inhibited chemical and radiation-induced breast tumours (Troll et al, 1980; Barnes et al, 1990; Constantinou et al, 1998), prostatic dysplasia (Mäkelä et al, 1991) and colon cancer (Weed et al, 1985; Thiagarajan et al, 1998). Cell culture experiments have also shown that soy bean constituents completely prevent or suppress the induction of tumours in various organs (reviewed by Herman et al, 1995). Epidemiological studies as well as animal and cell culture experiments therefore provide evidence that suggests that the intake of soy beans lowers the risk of cancer.

\section{Possible mechanisms in preventing cancer}

A number of different compounds in soy beans may be responsible for various types of anticarcinogenic activity. These compounds include a protease inhibitor (the Bowman-Birk inhibitor), a trypsin inhibitor, isoflavones (genistein and diadzein), saponins, inositol hexaphosphate (phytic acid) and the sterol, sitosterol (reviewed by Kennedy, 1995). Examples of different types of in vitro anticarcinogenic activity reported for a variety of soy bean constituents are summarised by Kennedy (1995). These constituents include the ability to prevent malignant transformation (protease inhibitor), the ability to suppress promotion (trypsin inhibitor), the inhibition of proliferate growth of human breast cancer cell lines in culture (genistein), and inhibition of the expression of an oncogenic virus (saponins).

Twenty to $25 \%$ of the total protease inhibitor content of soy bean protein is the Bowman-Birk inhibitor (BBI) (Kennedy, 1995). BBI has shown the greatest suppression of carcinogenesis in animal carcinogenesis assays. St Clair et al (1990) observed that BBI can completely prevent colon carcinogenesis (100\% suppression). It suppresses carcinogenesis in the liver by $71 \%$, in the oral epithelium by $86 \%$, and in the lung by $48 \%$. The ability of BBI to suppress carcinogenesis in the various systems that were studied far exceeds the ability of other soy bean-derived compounds (Kennedy, 1995). The anticarcinogenic activity of BBI has been observed in many different tissues, in many different cell types (including cells of epithelial and connective tissue origin), with many different types of carcinogenic agents, including ionising radiation used in the mammary carcinogenesis studies reported by Troll et al (1980) and chemical carcinogens used in the studies reported by Barnes et al (1990), reviewed by Kennedy (1993). The trypsin inhibitor inhibits the growth of a variety of malignant cell types in vitro, but this protease inhibitor does not have the ability to suppress oral carcinogenesis induced by 7,12dimethylbenzanthracene (DMBA) in hamsters (Messadi et al, 1986).

The observation of Barnes et al (1990) that both raw and autoclaved soy beans inhibited chemically induced mammary cancer in rats, was important because the protease inhibitors in soy beans, which are thought to be potent chemopreventive agents, are destroyed by autoclaving (Messina \& Messina, 1991). The data of Barnes et al suggested that the isoflavones in soy beans were responsible for tumour inhibition. In vitro genistein inhibits tyrosine protein kinases, DNA topo-isomerases and S6 kinases (Yamashita et al, 1990). The activity of these enzymes is enhanced in oncogene-transformed cells (Yamashita et al, 1990). Isoflavones may consequently have a role to play in preventing a wide range of cancers. Several studies have looked specifically at the oestrogenic/antioestrogenic effects of soy beans (Wilcox et al, 1990; Cassidy et al, 1995). These studies suggest that isoflavones possess both antioestrogenic and oestrogenic activity, and in premenopausal women soy consumption influences hormonal patterns in a way that is potentially protective against breast cancer (Messina \& Messina, 1991). Lamartiniere et al (1998) recently reported that pharmacologic doses of genistein given to mature rats enhance mammary gland differentiation, resulting in a significantly less proliferative gland that is not as susceptible to mammary cancer. These authors speculate that breast cancer protection in Asian women on traditional soy-containing diets is, in part, derived from early exposure to genistein-containing soy.

Three other compounds in soy beans have also been shown to suppress carcinogenesis in animals, namely saponins, phytic acid and -sitosterol. Saponins are cytotoxic to sarcoma cells in culture (Huang et al, 1982, in Kennedy, 1995) and they inhibit the expression of an oncogenic virus (Tokuda, 1988). Phytic acid was observed in one experiment on mice to suppress colon carcinogenesis by $25 \%$ (Shamsuddin et al, 1989). In an experiment in which the soy bean sterol B-sitosterol was assayed for its ability to sup- 
press colon carcinogenesis, the sterol was able to reduce the total number of benign and malignant tumours by 39\% (Raicht et al, 1980).

As discussed above, there are a number of different compounds in soy beans with various types of anticarcinogenic activity. For all of these compounds there are likely to be toxic effects that have to be studied along with their anticarcinogenic activities. Human cancer prevention trials of the isoflavones and of $\mathrm{BBI}$ have begun recently.

\section{BONE-STRENGTHENING EFFECTS OF SOY BEANS}

There are indications that soy beans reduce the incidence of postmenopausal osteoporosis. Genistein in low doses maintained bone mass in ovariectomised rat models (Anderson et al, 1995a; Arjmandi et al, 1996). Adlercreutz and Mazur (1997) reported some effects of soy or isoflavonoid intake in patients with menopausal symptoms such as hot flushes, vaginal dryness and bone resorption, and discussed the low incidence of menopausal problems in Japanese women compared to Canadian, American and Finnish women. The results of a study of the short-term effects of soy bean isoflavones on bone strength in postmenopausal women indicated that a high-soy diet increased bone mineral content and bone density in the lumbar spine (Erdman, 1998). Potter et al (1998) also reported a significant increase $(2 \%)$ in both bone mineral content and bone density in the lumbar spine of postmenopausal women after six months on a diet that included $40 \mathrm{~g}$ of protein per day from isolated soy protein containing $2,25 \mathrm{mg}$ isoflavones/g protein. Their findings are of interest for two reasons:

Firstly, of all the skeletel sites they measured, the spine is the area that is most sensitive to oestrogen because of its higher trabecular bone content. The spine is remodelled more rapidly than the hip which contains a higher proportion of cortical bone (Ettinger et al, 1992).

Secondly, although Potter et al (1998) had hypothesised that $a$ isoflavone-containing soy protein diet would delay the decrease in bone density (compared to the control diet), they actually found that there was a slight increase in bone density and mineral content. However, this was a short study with respect to bone, and these findings should be confirmed by more extensive studies (e.g. 2-3 years).

Arjmandi (1998) reported improvement in femoral bone density in rats that were fed soy protein isolate for 35 days compared to rats fed a casein-based diet. However, he recommends additional long-term studies to determine the effects of soy beans on maintaining bone health. Adlercreuz and Mazur (1997) suggest that isoflavonoids may to some degree inhibit osteoporosis but may be insufficient for complete protection as single prevention strategy.

\section{EFFECTS OF SOY ON THE MANAGEMENT OF DIA- BETES MELLITUS}

Both Jenkins et al (1984) and Anderson et al (1984) did extensive research on the role of dietary fibre in the management of diabetes. Recent studies suggest that blood glucose may be influenced by various dietary fibres, although usually the most effective fibre sources for control of diabetes are soluble fibres such as guar gum and pectin (Slavin, 1991). However, they are neither highly palatable nor acceptable for longterm therapy of diabetes. It is considerably easier to incorporate soy fibre in a meal without greatly affecting the texture and palatability of the meal.

Tsai et al (1987) studied seven obese patients with noninsulin-dependent diabetes mellitus (NIDDM). The subjects were given a standard meal with and without $10 \mathrm{~g}$ of soy fibre. The soy fibre supplement significantly enhanced the return of serum glucose levels to fasting levels during the latter half of the test meal. Soy fibre had no effect on plasma insulin. Verster (1993) studied the long-term effect of either an energyrestricted high-carbohydrate, high-fibre, low-fat (HCHFLF) diet with a daily addition of $150 \mathrm{~g}$ (cooked weight) of dry beans compared to the influence of the same diet with the addition of $50 \mathrm{~g}$ (raw weight) of soy protein isolate on the metabolic control of sixteen NIDDM patients for a twelve-week period. Both diets improved glycaemic control as indicated by decreased glycated haemoglobin $(\mathrm{HbA} 1)$ concentrations. Lo et al (1986) conducted glucose tolerance tests on patients with hyperlipidemia. Adding $25 \mathrm{~g}$ of soy fibre in a cookie to the diets of subjects significantly reduced their fasting glucose levels by $8,5 \%$. Thus, although some studies found a positive effect on control of diabetes, more research is needed in this area.

\section{RECOMMENTATIONS FOR OPTIMUM DIETARY IN- TAKE OF SOY PRODUCTS}

Oriental populations consume $20 \mathrm{mg}$ to $80 \mathrm{mg}$ of the isoflavone genistein per day, almost entirely derived from soy, whereas the dietary intake of genistein in the United States is only $1 \mathrm{mg}$ to $3 \mathrm{mg}$ per day (Barnes et al, 1996). Soy beans contain $100 \mathrm{mg}$ to $300 \mathrm{mg}$ of the isoflavones genistein and daidzein (Herman et al, 1995). According to Craig (1997), it is possible to obtain substantial levels of dietary isoflavones through the daily consumption of $30 \mathrm{~g}$ to $60 \mathrm{~g}$ of soy protein. One half-cup of soy beans, one cup of soy beverage or $120 \mathrm{~g}$ of tofu provide $30 \mathrm{mg}$ to $40 \mathrm{mg}$ of genistein. Soy bean concentrates prepared by alcohol extraction display no oestrogenic activity due to genistein extraction in aqueous ethanol, and soy protein isolates contain only small amounts of isoflavones (Nash et al, 1967).

\section{CONCLUSIONS}

Researchers are just beginning to understand the physiological and biochemical effects of soy consump- 
tion. Considerable progress has been made since the First International Symposium on the Role of Soy in Preventing Chronic Disease was held in 1995 (Messina et al, 1998). The potentially beneficial effects of soy consumption clearly indicate both the need and the justification for more clinical and experimental studies. Further studies are required to examine the effects of soy beans and soy bean products on cardiovascular risk factors, cancer, osteoporosis and the relief of menopausal symptoms. Although multiple factors are driving research on soy, the single most important factor is arguably that soy beans are a concentrated source of isoflavones. Whereas relatively little research on soy bean isoflavones had been conducted before 1993, well over 1000 studies dealing with isoflavones were published between 1994 and 1996 (Messina et al, 1998). Definite data about the relationship between soyfoods and isoflavones and the risk of chronic disease may be many years away. However, the foundation has now been laid for research to determine not only the effects of soy and isoflavones on serum lipids, but also on the incidence of heart disease; not only on bone mineral density, but also on fracture risk, and not only on biomarkers of cancer risk, but also on cancer rates.

\section{REFERENCES}

ADLERCREUTZ, H \& MAZUR, W (1997): Phytoestrogens and western diseases. Ann Med 29:95-100.

ANDERSON, JJ, AMBROSE, WW \& GARNER, SC (1995a): Orally dosed genistein from soy and prevention of cancellous bone loss in two ovariectomized rat models. Abstract. J Nutr 125:799S.

ANDERSON, JW, JOHNSTONE, BM \& COOK-NEWEL, ME (1995b): Meta-analysis of the effects of soy protein intake on serum lipids. N Engl J Med 333:276-282.

ANDERSON, J, STORY, C, SIBLING, B \& CHEN, W (1984): Hypocholesterolemic effects of high fibre diets rich in watersoluble plant fibres: long term studies with oat bran and bean supplemented diets for hypercholesterolemic men. Can Diet J 45:140-148.

ANTHONY, MS, BURKE, GL, HUGHES, CL Jr, CLARKSON, TB (1995a): Does soy supplementation improve coronary heart disease (CHD) risk? Abstract. Circulation 91:925.

ANTHONY, MS, CLARKSON, TB \& HUGHES, CL (1994):

Plant and mammalian estrogen effects on plasma lipids of female monkeys. Abstract. Circulation 90 (Suppl):1:235

ANTHONY, MS, CLARKSON, TB \& HUGHES, CL Jr (1996):

Soy bean isoflavones improve cardiovascular risk factors without affecting the reproductive system of peripubertal rhesus monkeys. J Nutr 126:43-50.

ANTHONY, MS, CLARKSON, TB, BULLOCK, BV \& WAGNER, JD (1997): Soy protein versus soy phytoestrogens in prevention of diet-induced coronary artery atherosclerosis of male cynomolgus monkeys. Arterioscler Thromb Vasc Biol 17:2524-2531.

ANTHONY, MS, CLARKSON, TB, WEDDLE, DL \& WOLFE MS (1995b): Effects of soy protein phytoestrogens on cardiovascular risk factors in rhesus monkeys. Abstract. J Nutr 125:803S-804S

ARJMANDI, B (1998): The ovarian hormone deficiencyinduced hypercholesterolemic is reversed by soy protein and the synthetic isoflavone, ipriflavone. http://www.talksoy.com/ treatosteo.htm

ARJMANDI, BH, ALEKEL, L HOLLIS, BW \& AMIN, D (1996): Dietary soybean protein prevents bone loss in OVX rat model of osteoporosis. J Nutr 126:161-167.

BAKHIT, RM, KLEIN, BP, ESSEX-SORLIE, D, HAM, JO,

ERDMAN, JW \& POTTER, SM (1994): Intake of $25 \mathrm{~g}$ of soybean protein with or without soybean fiber alters plasma lipids in men with elevated cholesterol concentrations. J Nutr 124:213-222.

BALMIR, F, STAACK, R, JEFFEREY, E, JIMEREZ, MDB, WAND, L \& POTTER, SM (1996): An extract of soy flour influences serum cholesterol and thyroid hormones in rats and hamsters. J Nutr 126:3046-3053.

BARNES, S, GRUBBS, C, SETCHELL, S \& CARLSON, J (1990): Soybeans inhibit mammary tumors in models of breast cancer, in Pariza, MW, Aeschbacher, HU, Eton, JS \& Sato, $\mathrm{S}$ (eds). Mutagens and carcinogens in the diet. New York. Wiley.

BARNES, S, SFAKIANOS, J, COWARD, L \& KIRK, M (1996): Soy isoflavones and cancer prevention. Underlying biochemical and pharmacological issues. Adv Exp Med Biol 401:87-100

BAUM, JA, TENG, H, ERDMAN, JW Jr, WEIGEL, RM, KLEIN, BP, PERSKY, VW, FREELS, S, SURYA, P, BAKHIT, RM, RAMOS, E, SHAY, NF \& POTTER, SM (1998): Long-term intake of soy protein improves blood lipid profiles and increases mononuclear cell low-densitylipoprotein receptor messenger RNA in hypercholesterolemic, postmenopausal women. Am J Clin Nutr 68:545551.

CARROLL, KK (1991): Review of clinical studies on cholesterol-lowering response to soy protein. J Am Diet Ass 91:820-827.

CASSIDY, A, BINGHAM, S \& SETCHELL, K (1995): Biological effects of isoflavonoids in young women: importance of the chemical composition of soyabean products. Br J Nutr 74:587-601.

CLARKSON, TB, ANTHONY, MS, WILLIAMS, JK, HONORE, EK \& CLINE, JM (1998): The potential of soybean phytoestrogens for postmenopausal hormone replacement therapy. Proc Soc Exp Biol Med 217:365-368.

CONSTANTINOU, AI, KRYGIER, AE \& MEHTA, RR (1998): Genistein induces maturation of cultured human breast cancer cells and prevents tumor growth in nude mice. Am J Clin Nutr 68 (suppl):426S-1430S.

COWARD, L, SMITH, M, KIRK, M \& BARNES, S (1998): Chemical modification of isoflavones in soyfoods during cooking and processing. Am J Clin Nutr 68 (suppl):1486514915

CRAIG, WJ (1997): Phytochemicals: guardians of our health. J Am Diet Ass 97 (suppl 2):S199-S204

DE WHALLEY, CV RANKIN, SM, HOULT, JRS, JESSUP, W \& LEAKE, DS (1990): Flavonoids inhibit the oxidative modification of low density lipoproteins by macrophages. Biochem Pharm 39:1743-1750.

ELRIDGE, A \& KWOLEK, WF (1983): Soy bean isoflavones: effect of environment and variety on composition. J Agri Food Chem 31:394-396.

ENGLYST, HN, BINGHAM, SA, RUNSWICK, SA, COLLINSON, E \& CUMMINGS, JH (1998): Dietary fibre (nonstarch polysaccharides) in fruit, vegetables and nuts. J Hum Nutr Dietet 1:247-286.

ERDMAN, JW Jr (1998): Short-term effects of soy bean isoflavones on bones in post-menopausal women. Second International Symposium on the Role of Soy in Preventing and Treating Chronic Disease. http://www.talksoy.com/ treatosteo.htm.

ETTINGER, $B$ GENANT, HK, STEIGER, $P$ \& MADVIG, $P$ (1992): Low-dosage micronized 17-estradiol prevents bone loss in postmenopausal women. Am J Obstet Gynecol 166:479-488.

FOOD AND NUTRITION BOARD, NATIONAL RESEARCH COUNCIL, NATIONAL ACADEMY OF SCIENCE (1989): Recommended dietary allowances. $10^{\text {th }} \mathrm{ed}$.

Washington, DC National Academy Press.

FORSYTHE, WA III (1986): Comparison of dietary casein or soy protein effects on plasma lipids and hormone concentrations in the gerbil. J Nutr 116:1165-1171.

FRANKE, AA, CUSTER, LJ, CERNA, CM \& NARALA, K (1995): HPLC analysis of dietary phytoestrogens from legumes and from human urine. Proc Soc Exp Bio Med 208:1826.

FUMAGALLI, KR, SOLERI, L, FARINA, R, MUSANTI, R, MANTERO, O, NOSEDA, G, GATTI, E \& SIRTORI, CR (1982): Fecal cholesterol excretion studies in type II hypercholesterolemic patients treated with the soyprotein diet. 
Atherosclerosis 43:341-353.

GRUNDY, SM \& ABRAMS, JJ (1983): Comparison of actions of soy protein and casein on metabolism of plasma lipoproteins and cholesterol in humans. Am J Clin Nutr 38:245 252.

HAM, JO, CHAPMAN, KM, ESSEX-SORLIE, D, BAKHIT, RM, PRABHUDESAI, M, WINTER, L, ERDMAN, JW \& POTTER, SM (1993): Endocrinological responses to soy protein and fiber in mildly hypercholesterolemic men. Nutr Res 13:873-884

HERMAN C, ADLERCREUTZ T, GOLDIN, BR GORBACH, SL, HÖCKERSTEDT, KAV, WATANABE, S, HÄMÄLÄINEN, EK, MARKANEN, MH, MÄKELA, TH, WÄHÄLÄ, KT, HASE, TA \& FOTSIS, T (1995): Soybean phytoestrogen intake and cancer risk. J Nutr 125:757S-770S.

HONORE, EK, WILLIAMS, JK, ANTHONY, MS \& CLARKSON, TB (1997): Soy isoflavones enhance coronary vascular reactivity in atherosclerotic female macaques. Fertil Steril 67:148-154

HUFF, MW \& CARROLL, KK (1980): Effects of dietary protein on turnover, oxidation, and absorption of cholesterol, and on steroid excretion in rabbits. J Lipid Res 21:546-558.

HUFF, MW, HAMILTON, RMG \& CARROLL, KK (1977): Plasma cholesterol levels in rabbits fed low fat, cholesterolfree, semipurified diets: effects of dietary proteins, protein hydrolysates and amino acid mixtures. Atherosclerosis 28:187-195

JENKINS, DJA, WOLEVER, TMS, THORNE, MJ, JENKINS, AL, WONG, GD \& JOSSE, RG (1984): The relation between glycemic response, digestibility, and factors influencing the dietary habits of diabetics. Am J Clin Nutr 40:1175-1191.

KANAZAWA, T, OSANAI, T, ZHANG, XS, UEMURA, T, YIN, $X Z$, ONODERA, K, OIKE, Y \& OHKUBO, K (1995): Protective effects of soy protein on the peroxidizability of lipoproteins in cerebrovascular disease. J Nutr 125:639S-646S. KAPIOTIS, S, HERMANN, M, HELD, I, SEELOS, C, EHRINGER, H \& GMEINER, BMK (1997): Genistein, the dietary-derived angiogenesis inhibitor, prevents LDL oxidation and protects endothelial cells from damage by atherogenic LDL. Arterioscler Thromb Vasc Biol 17:2868-2874. KENNEDY, AR (1993): Cancer prevention by protease inhibitors. Prev Med 22:796-811.

KENNEDY, AR (1995): The evidence for soybean products as cancer preventive agents. J Nutr 125:733S-743S.

KNIGHT, DC \& EDEN, JA (1996): A review of the clinical effects of phytoestrogens. Obstet Gynecol 87:897-904.

KURZUR, MS \& XU, X (1997): Dietary phytoestrogens. Annu Rev Nutr 17:353-381.

LAMARTINIERE, CA, ZHANG, J-X \& COTRONEO, MS (1998): Genistein studies in rats: potential for breast cancer prevention and reproductive and developmental toxicity. Am $\mathrm{J}$ Clin Nutr 68 (suppl):1400S-1405S.

LANGENHOVEN, M, KRUGER, M, GOUWS, E \& FABER, M (1991): MRC food composition tables. Parow: Medical Research Council.

LEE, HP, GOURLEY, L, DUFFY, SW, ESTEVE, J, LEE, J \& DAY, NE (1991): Dietary effects on breast-cancer risk in Singapore. Lancet 337:1197-1200.

LICHTENSTEIN, AH (1998): Soy protein, isoflavones and cardiovascular disease risk. j Nutr 128:1589-1592.

LO, GS, GOLDBERG, AP, LIM, A, GRUNDHAUSER, JJ, ANDERSON, C \& SCHONFELD, G (1986): Soy fiber improves lipid and carbohydrate metabolism in primary hyperlipidemic subjects. Atherosclerosis 62:239-248. LOVATI, MR, MANZONI, C, CANAVESI, A, SIRTORI, M, VACCARINO, V, MARCHI, M, GADDI, G \& SIRTORI, CR (1987): Soy bean protein diet increases low density lipoprotein receptor activity in mononuclear cells from hypercholesterolemic patients. J Clin Invest 80:1498-1502

MÄKELÄ, S, PYLKKÄNEN, L, SANTI, R \& ADLERCREUTZ, $H$ (1991): Role of plant estrogens in normal and estrogenrelated altered growth of the mouse prostate, in EURO FOOD TOX III. Proceedings of the Interdisciplinary Conference on Effects of Food on the Immune and Hormonal Systems. Zürich: Swiss Federal Institute of Technology.

MESSADI, PV, BILLINGS, P, SHKLAR, G \& KENNEDY, AR (1986): Inhibition of oral carcinogenesis by a protease inhibitor. J Natl Cancer Inst 76:447-452.

MESSINA, M, DESCHEEMAKER, $K$ \& ERDMAN, JW Jr (1998): Preface. Am J Clin Nutr 68 (suppl):1329.
MESSINA, M \& MESSINA, V (1991): Increasing use of soyfoods and their potential role in cancer prevention. J Am Diet Assoc 91:836-840.

MURPHY, PA (1982): Phytoestrogen content of processed soy bean products. Food Technol 34:60-64.

NAGAOKA, $S$, AWANO, R, NAGATA, N, MASAOKA, $M$ HORI, G \& HASHIMOTO, K (1997): Serum cholesterol re duction and cholesterol absorption inhibition in Caco-2 cells by a soyprotein peptic hydrolyzate. Biosci Biotechnol Biochem 61:354-356.

NAGASAWA, H (1980): Nutrition and breast cancer: a survey of experimental and epidemiological evidence. IRCS J Med Sci 8:317-325.

NAGATA, Y, ISHIWAKI, N \& SUGANO, M (1982): Studies on the mechanism of the antihypercholesterolemia action of soy protein and soy protein-type amino acid mixtures in relation to their casein counterparts in rats. J Nutr 112:16141625

NASH, AM, ELDRIDGE, AC \& WOLF, WJ (1967): Fractionation and characterization of alcohol extractables associated with soybean proteins. Nonprotein components. J Agric Food Chem 15:102-107.

NESTEL, PJ, YAMASHITA, T \& SASAHARA, T (1997): Soy isoflavones improve systemic arterial compliance but not plasma lipids in menopausal and perimenopausal women. Arterioscler Thromb Vasc Bio 17:3392-3398.

OAKENFULL, DG (1981): Saponins in food. A review. Food Chem 7:19-40.

PELLETIER, $X$, BELBRAOUET, $S$, MIRABEL, D, MORDRET, F, PERRIN, JL, PAGES, X \& DERBY, G (1995): A diet moderately enriched in phytosterols lowers plasma cholesterol concentrations in normocholesterolemic humans. Ann Nutr Metab 39:291-295.

POTTER, SM (1995): Overview of possible mechanisms for the hypocholesterolemic effect of soy protein. J Nutr 125:606S-611S.

POTTER, SM (1998): Soy protein and cardiovascular disease: the impact of bioactive components in soy. Nutr Rev 56(8):231-235

POTTER, SM, BAKHIT, RM, ESSEX-SORUE, D, WEINGARTNER, KE, CHAPMAN, KM, NELSON, RA, PRABHUDESAI, M, SAVAGE, WD, NELSON, Al, WINTER, LW \& ERDMANN, JW, Jr (1993): Depression of plasma cholesterol in men by consumption of baked products containing soy protein. Am J Clin Nutr 58:501-506.

POTTER, SM, BAUM, JA TENG, H, STILLMAN, RJ SHAY, NF \& ERDMAN, JW Jr (1998): Soy protein and isoflavones: their effects on blood lipids and bone density in postmenopausal women. Am J Clin Nutr 68 (suppl):13755-13795.

POTTER, SM, BERBER-JIMENZ, MD \& PERTILE, JC (1996): Protein from soy concentrate and isolated soy protein alters blood lipids and hormones differently. J Nutr 126:2007-2011.

POTTER, JD, TOPPING, DL \& OAKENFULL, D (1979): Soya, saponins and plasma cholesterol. Lancet 1:233.

RAICHT, RF, COHEN, BI, FAZZINI, EP, SARWAL, AN \& TAKAHASHI, M (1980): Protective effect of plant sterols against chemically induced colon tumors in rats. Cancer Res 40:403405.

RUIZ-LARREA, MB, MOHAN, AR, PAGANGA, G, MILLER, NJ \& BOLWELL, GP (1997): Antioxidant activity of phytoestrogenic isoflavones. Free Radic Res 26:63-70.

SCHOLZ-AHRENS, KE, HAGEMEISTER, H, UNSHELM, J, AGERGAARD, N \& BARTH, CA (1990): Response of hormones modulating plasma cholesterol to dietary casein or soy protein in minipigs. J Nutr 120:1387-1392.

SETCHELL, KDR (1998): Phytoestrogens: the biochemistry, physiology, and implications for human health of soy isoflavones. Am J Clin Nutr 68 (suppl):1333S-1346S.

SEVERSON, RK, NOMURA, AYM, GROVE, JS \& STEMMERMAN, GM (1989): A prospective study of demographics and prostate cancer among men of Japanese ancestry in Hawaii. Cancer Res 49:1857-1860.

SHAMSUDDIN, AM, ULLAH, A \& CHAKRAVARTHY, AK (1989): Inositol and inositol hexaphosphate suppress cell proliferation and tumor formation in CD-1 mice. Carcinogenesis 10:1461-1463.

SHIMUZU, H, ROSS, RK, BERNSTEIN, L, YATANI, R, HENDERSON, BE \& MACK, TM (1991): Cancers of prostate and breast among Japanese and white immigrants in Los An- 
geles county. Br J Cancer 63:963-966.

SHOREY, RL, DAY, PL, WILLIS, RA, LO, GS \& STEINKE, $\mathrm{FH}$ (1985): Effects of soybean polysaccharide on plasma lipids. J Am Diet Assoc 85:1461-1465.

SLAVIN, J (1991): Nutritional benefits of soy protein and soy fiber. J Am Diet Assoc 91:816-819.

SNYDER, HE \& KWON, TW (1987): Soybean utilization. New York. Van Nostrand Reinhold.

SONG, T, BARUA, K, BUSEMAN, G \& MURPHY, A (1998):

Soy isoflavone analysis: quality control and a new internal standard. Am J Clin Nutr 68 (suppl):14745-14795.

STEELE, MG (1992): The effect on serum cholesterol levels of substituting milk with a soya beverage. Aust J Nutr Diet 49:24-28.

ST CLAIR, W, BILLINGS, P, CAREW, J, KELLERMCGANDY, C, NEWBERWE, P \& KENNEDY, AR (1990): Suppression of DMH-induced carcinogenesis in mice by dietary addition of the Bouman-Birk protease inhibitor. Cancer Res 50:580-586.

SUGANO, M \& KOBA, K (1993): Dietary protein and lipid metabolism: a multifunctional effect. Ann NY Acad Sci 676:215-222.

TANAKA, K, ASO, B \& SUKANO, M (1984): Biliary steroid excretion in rats fed soybean protein and casein or their amino acid mixtures. J Nutr 114:26-32.

TASKER, TE \& POTTER, SM (1993): Effects of dietary protein source on plasma lipids, HMG CoA reductase activity, and hepatic glutathione levels in gerbils. J Nutr Biochem 4:458-462.

THIAGARAJAN, DG, BENNINK, MR, BOURQUIN, LD \& KAVAS, FA (1998): Prevention of precancerous colonic lesions in rats by soy flakes, soy flour, genistein, and calcium. Am J Clin Nutr 68 (suppl):1394S-1399S.

TOKUDA, H (1988): Inhibitory effects of 12-0tetradecanoylphorbol-13-acetate and teleocidin-B-induced Epstein-Barr virus by saponin and its related compounds. Cancer Lett 40:309-317.

TROLL, W, WIESNER, R, SHELLABARGER, J, HOLTZMAN, S \& STONE, JP' (1980): Soybean diet lowers breast tumour incidence in irradiated rats. Carcinogenesis 1:469-
472.

TSAI, AC, MOTT, EL, OWEN, GM, BENNICK, MR, LO, GS \& STEINKE, FS (1983): Effects of soy polysaccharide on gastrointestinal function, nutrient balance, steroid excretion, glucose tolerance, serum lipids and other parameters in humans. Am J Clin Nutr 38:504-511.

VERSTER, A (1993): Die langtermyninvloed van droëbone en soja op die metaboliese beheer van Tipe II diabetes mellitus-pasiënte. MSc Dieetkunde-verhandeling. Potchefstroom Universiteit vir $\mathrm{CHO}$.

WATANABE, S \& KOESSEL, S (1993): Colon cancer: an approach from molecular epidemiology. J Epidemiol 3:47-61. WEED, HG, MCGANDY, RB \& KENNEDY, AR (1985): Protection against dimethylhydrazine-induced adenomatous tumors of the mouse colon by the dietary addition of an extract of soy beans containing the Bowman-Birk protease inhibitor. Carcinogenesis 6:1239-1241.

WILCOX, G, WAHLQVIST, ML, BURGER, HG \& MEDLEY, G, (1990): Oestrogenic effects of plant foods in postmenopausal women. Br Med J 301:905-906.

WOLF, BM, GIOVANETTI, PM, CHENG, DCH, ROBERTS, DCK \& CARROLL, KK (1981): Hypolipidemic effect of substituting soybean protein isolate for all meat and dairy protein in the diets of hypercholesterolemic men. Nutr Rep Int 24:11871198.

WU, AH, ZIEGLER, RG, NOMURA, AMY, WEST, DW, KOLONEL, LN, HORN-ROSS, PL, HOOVER, RN \& PIKE, MC (1998): Soy intake and risk of breast cancer in Asians and Asian Americans. Am J Clin Nutr 68 (suppl):1437S-14435S.

YAMASHITA, U, KAWADA, S \& NAKANO, H (1990): Induction of mammalian topoisomerase II dependent DNA cleavage by noninteractive flavonoids, genistein and equol. Biochem Pharm 39:737-744.

YUAN, J-M, WANG, Q-S, ROSS, RK, HENDERSON, BE \& YU, MC (1995): Diet and breast cancer in Shanghai and Tianjin, China. Br J Cancer 71:1353-1358. 